\title{
Pengembangan Lembar Kerja Peserta Didik (LKPD) Sosiologi Berbasis Weblog Pada PembeIajaran Sosiologi Kelas X SMA
}

\author{
Sintya Ulfa Dilla ${ }^{1}$, Ike Sylvia ${ }^{2}$ \\ ${ }^{1,2}$ Universitas Negeri Padang \\ Email: sintyafadilla88@gmail.com, ikesylvia@fis.unp.ac.id
}

\begin{abstract}
Abstrak
Penelitian ini bertujuan untuk mengembangkan dan menguji praktikalitas Lembar Kerja Peserta Didik (LKPD) berbasis weblog untuk mengakodomodasi kemampuan peserta didik menguasai materi (domain kognitif). Penelitian ini menggunakan model $4 \mathrm{D}$ (define, design, develop, disseminate). Pada tahap uji praktek dilakukan dalam dua tahap yaitu uji satu banding satu (1 orang pengguna) dan uji kelompok lapangan (40 pengguna). Adapun indikator yang digunakan pada angket praktikalitas LKPD berbasis weblog ini adalah minat pengguna terhadap tampilan LKPD, proses penggunaan, pemahaman konsep dan materi, waktu yang disediakan serta evaluasi dalam LKPD. Hasil uji coba tahap pertama, guru sosiologi menilai sangat praktis dengan nilai akhir 3,84. dan pada uji coba kedua memperoleh hasil bahwa LKPD berbasis web blog ini sangat praktis diterapkan kepada pengguna yaitu peserta didik di kelas X IPS 3 SMAN 1 Batusangkar dengan nilai uji praktikalitas sebesar 3,7. Berdasarkan hasil tersebut LKPD Sosiologi berbasis weblog untuk peserta didik kelas XI IPS yang diujicobakan di SMAN 1 Batusangkar sangat praktis untuk digunakan dan dapat dimanfaatkan oleh pengguna lain yang mempelajarkan materi yang sama karena LKPD ini tersedia dalam bentuk digital pada weblog.
\end{abstract}

Kata kunci: Lembar Kerja Peserta Didik, Model 4-D, Weblog

\section{Absract}

This study aims to develop and test the practicality of webblog-based Student Worksheets (LKPD) to accommodate students' abilities to master the material (cognitive domain). This study uses a $4 \mathrm{D}$ model (define, design, develop, disseminate). In the practical test stage, it is carried out in two stages, namely the one to one test (1 user) and the field group test (40 users). The indicators used in this weblog based LKPD practicality questionnaire are user interest in the LKPD display, the process of use, understanding of concepts and material, the time provided and evaluation in the LKPD. The results of the first phase of the trial, the sociology teacher considered it very practical with a final score of 3.84. and in the second trial, the results showed that this web blog based LKPD was very practical to be applied to users, namely students in class XIPS 3 SMAN 1 Batusangkar with a practicality test value of 3.7. Based on these results, the weblog-based Sociology LKPD for class XI IPS students tested at SMAN 1 Batusangkar is very practical to use and can be used by other users who are learning the same material because this LKPD is available in digital form on the weblog.

Keywork: Studend Worksheet, Weblog, 4-D Models

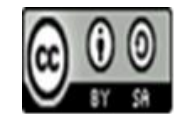




\section{PendahuIuan}

Pembelajaran merupakan suatu kegiatan dalam rangka melaksanakan kurikulum pada suatu lembaga pendidikan, untuk membantu peserta didik mencapai tujuan pendidikan yang telah ditetapkan. Pembelajaran merupakan interaksi dua arah antara guru dan peserta didik, yang terjadi komunikasi yang intens dan terarah menuju pada suatu target yang telah ditetapkan sebelumnya (Trianto, 2010). Pernyataan di atas merupakan penjelasan dari pernyataan yang terdapat dalam Undang-Undang Nomor 20 Tahun 2003 Pasal 1 Ayat (20) tentang Sistem Pendidikan Nasional bahwa "Pembelajaran adalah proses interaksi peserta didik dengan pendidik dan sumber belajar pada suatu lingkungan belajar." Interaksi antara guru dan peserta didik diharapkan dapat mengembangkan daya pikir dan kemampuan peserta didik dalam suatu materi belajar, proses ini akan berjalan dengan baik jika didukung dengan adanya pemanfaatan sumber belajar dan media pembelajaran. Pembelajaran di abad 21 mengalami pergeseran yaitu dengan mengintegrasikan proses pembelajaran dengan kemampuan literasi, kecakapan sikap, pengetahuan, keterampilan, dan penguasaan terhadap teknologi. (Sylvia, Anwar, \& Khairani, 2019). Hal ini ditujukan agar peserta didik dapat memiliki kemampuan yang membuat mereka dapat beradaptasi dengan perubahan. Oleh karena itu guru dituntut untuk memiliki kreativitas agar pembelajaran yang mereka lakukan dapat mengasah kompetensi peserta didiknya serta mampu menyediakan pengalaman belajar yang sesuai dengan kompetensi yang diharapkan dalam mata pelajaran yang diampunya.

Salah satu penunjang dalam proses pembelajaran adalah sumber belajar. Sumber belajar dapat berupa buku teks, media cetak, media elektronik, narasumber, lingkungan alam sekitar, dan lainnya yang dapat meningkatkan keefektifan proses pembelajaran. Sumber belajar yang bervariasi akan memberikan pengalaman yang luas kepada peserta didik. Sumber belajar berupa bahan belajar adalah rujukan, referensi, atau literatur yang digunakan oleh pengajar dalam mengajar (Munir, 2008). Sumber belajar mempunyai peran penting dalam proses pembelajaran yang efektif dan efisien. Pemilihan sumber belajar mengacu pada perumusan yang ada dalam silabus. Sumber belajar mencangkup sumber rujukan, lingkungan, media, narasumber, alat dan bahan yang dituliskan secara lebih operasional (Daryanto, 2014). Menurut Asosiasi Teknologi Komunikasi Pendidikan/AECT dalam (Bambang, 2008) sumber belajar adalah meliputi semua sumber, baik berupa data, barang atau benda yang dapat digunakan untuk memberi fasilitas (kemudahan) belajar bagi peserta didik. Sumber belajar memiliki fungsi untuk membantu peserta didik mencapai kompetensi, membantu pengajar daIam mengefisienkan waktu pembelajaran dan menghasilkan pembelajaran yang efektif, mendukung terlaksananya program pembelajara yang sistematis, mengingkatkan keberhasilan pembelajaran, mempermudah peserta didik mendapatkan pembelajaran yang berpusat pada peserta didik, memberikan informasi yang lebih luas tidak terbatas ruang dan waktu (Aprilia, 2019).

Seiring dengan perkembangan teknologi di bidang informasi dan komunikasi serta didukung oleh kemajuan teknologi hal ini juga memberikan dampak pada perkembangan dan pembaharuan pada sumber belajar. Sudah saatnya pendidikan menggunakan alternatif cara belajar baru yang bersahabat dengan teknologi. Contoh pembaharuan adalah dengan menggunakan berbagai aplikasi berbasis digital yang dapat memudahkan peserta didik dalam mengakses materi, seperti penggunaan e-book, e-modul, e-lkpd, dan lain sebagainya.

Salah satu sumber belajar dan media pembelajaran yang dapat membantu guru maupun peserta didik dalam proses pembelajaran adalah lembar kerja peserta didik (LKPD). LKPD dapat dikategorikan sebagai sumber belajar dengan jenis alat (material), dimana sumber belajar dalam bentuk material ini merupakan suatu format yang digunakan untuk menyimpan pesan pembelajaran, seperti buku teks, buku paket, modul, program video, film, alat peraga dan lain sebagainya (Aprilia, 2019). LKPD merupakan salah satu sumber belajar untuk membantu dan mempermudah dalam proses pembelajaran, sehingga terbentuk interaksi yang efektif antara pendidik dengan peserta didik. Tujuan penggunaan LKPD dalam proses belajar mengajar adalah

Jurnal Sikola: Jurnal Kajian Pendidikan dan Pembelajaran Vol. 2, No. 4, Th. 2021 
mengaktifkan peserta didik dalam proses pembelajaran dan memberikan pengetahuan, sikap dan keterampilan, yang perlu dimiliki oleh peserta didik (Syamsurizal, Epinur, \& Marzelina, 2014).

Untuk mencapai tujuan pembelajaran sosiologi dalam ruang kelas maka dibutuhkan upaya pengembangan sumber belajar yang efektif dan efisien. Salah satunya melalui penggunaan LKPD. Penyajian LKPD Sosiologi pada umumnya hanya sebatas materi ajar dan penugasan. Biasanya penyajian LKPD ini berbentuk lembaran kertas kerja yang didistribusikan kepada peserta didik. Keberadaan LKPD memberi pengaruh yang cukup besar dalam proses pembelajaran. Adapun proses belajar tersebut dapat diukur baik melalui tes perilaku, tes kemampuan kognitif, maupun tes psikomotorik (Nurcahyo, 2016).

LKPD berisi kumpulan kegiatan mendasar yang harus dilakukan oleh peserta didik untuk memaksimalkan pemahaman dalam upaya pembentukan kemampuan dasar sesuai indikator pencapaian belajar yang harus ditempuh (Munir, 2008). LKPD yang digunakan dalam kegiatan pembelajaran seharusnya sesuai dengan tuntutan Kompetensi Dasar (KD), dapat memotivasi peserta didik, dan menarik minat serta perhatian peserta didik untuk belajar (Pratama \& Siregar, 2019). Keuntungan penggunaan LKPD adalah memudahkan pendidik dalam melaksanakan proses pembelajaran. Peserta didik bisa belajar mandiri dan mudah memahami materi serta bisa menjalankan suatu tugas tertulis. Peserta didik memperoleh catatan tentang materi yang dipelajari melalui kegiatan belajar. LKPD juga dapat membantu peserta didik menambah informasi tentang konsep yang akan dipelajari melalui belajar secara sistematis.

Oleh karena itu, perlu dikembangkan sumber belajar yang ekonomis dari segi biaya, praktis dari segi penggunaan, fleksibel diakses oleh peserta didik, efisien, relevan dengan keadaan saat ini, memiliki nilai positif dan sesuai dengan rencana pembelajaran yang telah dirancang. Salah satu alternatif dalam penyediaan sumber belajar yang dapat digunakan dalam mendukung proses pembelajaran yang sesuai dengan kebermanfaatan baik bagi guru dan peserta didik adalah menggunakan weblog. Weblog merupakan salah satu referensi acuan yang memberikan sumbangan materi pembelajaran untuk para peserta didik yang disesuaikan dengan kurikulum terbaru (Refika, Suasti, \& Nofrion, 2018). Pada pembelajaran sosiologi saat ini sangat jarang ditemukan LKPD yang menggunakan weblog. Penggunaan weblog sebagai sumber belajar sebenarnya memiliki beberapa keunggulan. Diantaranya seperti akses yang mudah, tampilan menarik, dan tidak banyak mengeluarkan biaya. Apalagi dalam keadaan pandemi saat ini, LKPD berbasis weblog ini juga akan membuat pembelajaran lebih bervariasi. Sumber belajar berbasis weblog merupakan sumber belajar yang disusun dan dikembangkan dengan memanfaatkan fasilitas internet secara positif. Sumber belajar berbasis blog tergolong dalam blog pendidikan yang biasanya ditulis oleh pelajar atau guru dengan konten mengenai pendidikan (Madcom, 2010).

Penelitian terkait dengan pengembangan LKPD berbasis weblog ini memperlihatkan hasil relatif mudah dan murah serta dalam penyusunan isi bisa disesuaikan dengan karakteristik guru dan peserta didik, sehingga perlu dipertimbangkan oleh guru karena LKPD berbasis weblog ini mendukung penyampaian pesan melalui gambar, video, teks dan suara, sehingga penyampaian materi menjadi lebih menarik dibandingkan dengan penjelasan biasa. Akses ke weblog juga lebih mudah dan praktis serta memiliki sifat mobile friendly. (Manurung, 2018). Selain itu LKPD berbasis weblog efektif untuk meningkatkan literasi peserta didik (Usra, 2018), dapat menjadi media pembelajaran interaktif bagi peserta didik, mudah digunakan, dapat melatih kemandirian belajar peserta didik, sesuai dengan perkembangan teknologi, dan memfasilitasi guru dan peserta didik untuk berdiskusi jarak jauh. (Sari, 2018).

Oleh karena itu perlu dilakukan pengembangan sumber belajar sosiologi berbasis weblog agar terjadi interaksi guru dengan peserta didik yang dinamis dalam pembelajaran, meningkatkan kemampuan literasi peserta didik serta inovasi guru dalam mengembangkan perangkat pembelajaran berbasis teknologi. Tampilan yang menarik dan didukung gambar dapat meningkatkan daya pikir anak dalam menganalisis fenomena yang ditampilkan, bahan ajar yang 
lengkap dapat menambah wawasan peserta didik dalam pembelajaran, serta peserta didik dapat melatih pengetahuan dengan adanya soal evaluasi (Refika et al., 2018). Penggunaan belajar berbasis blog dapat memaksimalkan penggunaan fasilitas yang disediakansekolah karena sumber belajar ini memberikan beberapa keuntungan. Sumber belajar dapat diakses kapanpun dan dimanapun, hemat, interaktif,terbuka, mudah dan cepat (Politeknik, 2012).

\section{Metode Penelitian}

Penelitian pengembangan LKPD berbasis weblog ini adalah penelitian dengan jenis pengembangan (Research and Development) atau disingkat dengan R\&D. Model pengembangan yang digunakan adalah model $4 \mathrm{D}$ (define, design, develop, disseminate). Penelitian ini sesuai dengan level Kerangka Kualifikasi Nasional Indonesia (KKNI), pada level S1 yaitu pada level 6 KKNI yaitu mengaplikasikan, mengkaji, membuat desain, memanfaatkan IPTEK, dan menyelesaikan masalah. Penelitian pengembangan adalah suatu proses yang dipakai untuk mengembangkan dan memvalidasi produk pendidikan (Setyosari, 2010). Penelitian diadakan pada semester II tahun ajaran 2020/2021. Tempat penelitian dilaksanakan di SMA N 1 Batusangkar. Objek penelitian ini adalah lembar kerja peserta didik (LKPD) sosiologi berbasis weblog wordpress untuk SMA kelas X semester I. Subjek penelitian terdiri dari peserta didik dan guru SMA N 1 Batusangkar. Terdiri atas 1 orang guru sosiologi dan 40 orang peserta didik keIas X IPS 3. Pada tahap uji praktek dilakukan dalam dua tahap yaitu uji satu banding satu (1 orang pengguna) dan uji kelompok lapangan (40 pengguna). Instrumen yang digunakan dalam mengumpulkan data penelitian ini adalah sebagai berikut:

\section{Angket kepraktisan}

Angket ini berisi pertanyaan dan penyataan mengenai LKPD yang dikembangkan. Angket ini diisi oleh guru dan peserta didik yang bertujuan untuk mendapatkan tanggapan, saran dan kritikan untuk perbaikan sehingga LKPD sosiologi berbasis weblog yang dikembangkan benarbenar menjadi media yang praktis digunakan dalam proses pembelajaran. Berikut adalah kisi-kisi angket kepraktisan.

\section{Tabel 1. Kisi-Kisi Angket Uji Praktikalitas Oleh Guru}

\begin{tabular}{|c|c|c|c|}
\hline No & Variabel Validitas & Indikator & $\begin{array}{c}\text { Nomor } \\
\text { Pernyataan }\end{array}$ \\
\hline \multirow[t]{3}{*}{1} & $\begin{array}{l}\text { Minat peserta didik } \\
\text { dan tampilan LKPD }\end{array}$ & $\begin{array}{l}\text { a. Tampilan LKPD menarik minat peserta didik untuk } \\
\text { menggunakan LKPD }\end{array}$ & $1-2$ \\
\hline & & $\begin{array}{l}\text { b. Ketertarikan peserta didik terhadap gambar yang } \\
\text { ada pada LKPD }\end{array}$ & $3-4$ \\
\hline & & $\begin{array}{l}\text { c. Ketertarikan peserta didik terhadap pembelajaran } \\
\text { sosiologi dengan menggunakan LKPD }\end{array}$ & $5-8$ \\
\hline \multirow[t]{3}{*}{2} & Proses penggunaan & $\begin{array}{l}\text { a. LKPD lebih praktis dan penggunaannya dapat } \\
\text { disesuaikan dengan kecepatan belajar peserta didik } \\
\text { b. Pengounaan LKPD danat membantu peran guru }\end{array}$ & $9-11$ \\
\hline & & dalam pembelajaran & $12-15$ \\
\hline & & $\begin{array}{l}\text { c. Penggunaan LKPD membuat pelajaran menjadi } \\
\text { lebih efektif dan aktif serta meningkatan kualitas } \\
\text { hasil helaiar }\end{array}$ & $16-18$ \\
\hline \multirow[t]{3}{*}{3} & $\begin{array}{l}\text { Pemahaman konsep } \\
\text { dan materi }\end{array}$ & $\begin{array}{l}\text { a. LKPD membuat peserta didik dapat } \\
\text { menghubungkan materi yang dipelajari dengan } \\
\text { konteks nyata kehidupan sehari-hari }\end{array}$ & 19 \\
\hline & & b. LKPD dapat meningkatkan daya ingat peserta didik & $20-21$ \\
\hline & & c. LKPD membantu pemahaman materi dan konsep & $22-23$ \\
\hline 4 & Waktu & Penggunaan menghemat waktu & 24 \\
\hline 5 & Evaluasi & Latihan membantu peserta didik memahami konsep & 25 \\
\hline
\end{tabular}

Sumber: Dimodifikasi dari Nirmala (2011)

Jurnal Sikola: Jurnal Kajian Pendidikan dan Pembelajaran Vol. 2, No. 4, Th. 2021 
Setelah LKPD ini diuji kepraktisannya oleh guru sosiologi maka selanjutnya uji kepraktisan juga dilakukan kepada peserta didik kelas X, berikut kisi-kisi angket uji praktikalitas yang diisi oleh peserta didik oleh peserta didik:

\section{Tabel 2. Kisi-kisi Uji Praktikalitas oleh Peserta Didik}

\begin{tabular}{|c|c|c|c|}
\hline No & Variabel Validitas & Indikator & $\begin{array}{c}\text { Nomor } \\
\text { Pernyataan }\end{array}$ \\
\hline 1 & $\begin{array}{l}\text { Minat peserta didik dan } \\
\text { tampilan LKPD }\end{array}$ & $\begin{array}{l}\text { a. Tampilan LKPD menarik minat peserta } \\
\text { didik untuk menggunakan LKPD } \\
\text { b. Ketertarikan peserta didik terhadap } \\
\text { gambar yang ada pada LKPD } \\
\text { c. Ketertarikan peserta didik terhadap } \\
\text { pembelajaran sosiologi dengan } \\
\text { menggunakan LKPD }\end{array}$ & $\begin{array}{l}3-4 \\
5-6\end{array}$ \\
\hline 2 & Proses penggunaan & $\begin{array}{l}\text { a. LKPD lebih praktis dan pengunaannya } \\
\text { dapat disesuaikan dengan kecepatan } \\
\text { belajar peserta didik } \\
\text { b. Penggunaan LKPD meningkatkan hasil } \\
\text { aktivitas belajar peserta didik }\end{array}$ & $7-9$ \\
\hline 3 & $\begin{array}{l}\text { Pemahaman konsep dan } \\
\text { materi }\end{array}$ & $\begin{array}{l}\text { a. LKPD membuat peserta didik dapat } \\
\text { menghubungkan materi yang dipelajari } \\
\text { dengan konteks nyata kehidupan sehari- } \\
\text { hari } \\
\text { b. LKPD dapat meningkatkan dan } \\
\text { merangsang daya ingat peserta didik } \\
\text { c. LKPD membantu pemahaman materi } \\
\text { dan konsep }\end{array}$ & $\begin{array}{l}12-13 \\
14-15\end{array}$ \\
\hline 4 & Waktu & Penggunaan LKPD menghemat waktu & 16 \\
\hline 5 & Evaluasi & $\begin{array}{l}\text { Latihan membantu peserta didik } \\
\text { memahami konsep }\end{array}$ & 17 \\
\hline
\end{tabular}

Sumber: dimodifikasi dari Nirmala, 2011

Kisi-kisi angket di atas kemudian dikembangkan dalam bentuk skala likert dengan bobot sebagai berikut:

SS : : sangat setuju dengan bobot 4

S : : setuju dengan bobot 3

TS : tidak setuju dengan bobot 2

STS : sangat tidak setuju dengan bobot 1

Selanjutnya untuk menguji data dari uji praktikalitas yang diperoleh dari guru dan peserta didik dianalisis menggunakan rumus sebagai berikut:

$$
\overline{\mathrm{X}}=\frac{\sum x}{N}
$$

Keterangan:

$$
\begin{array}{ll}
\overline{\mathrm{x}} & \text { : nilai rata-rata responden } \\
\Sigma X & \text { : jumlah nilai seluruh responden } \\
\mathrm{N} & \text { : jumlah responden }
\end{array}
$$

Setelah nilai kepraktisan diperoleh, dilakukan pengelompokan sesuai kriteria yang dimodifikasi dari (Sudjana, 2006). 
TabeI 3. Nilai Kepraktisan

\begin{tabular}{cc}
\hline Nilai & Keterangan \\
\hline $3,50-4,00$ & Sangat Praktis (SP) \\
\hline $3,00-3,49$ & Praktis (P) \\
\hline $2,00-2,99$ & Cukup Praktis (CP) \\
\hline $1,00-1,99$ & Tidak Praktis (TP) \\
\hline
\end{tabular}

Sumber: (Sudjana, 2006)

\section{Hasil Penelitian dan Pembahasan}

\section{Proses Pengembangan LKPD}

\section{Tahap Define (Pendefinisian)}

a) Analisis Awal Akhir

Berdasarkan hasil penelitian yang peneliti lakukan di SMA N 1 Batusangkar diketahui bahwa masih ada kendala dalam penggunaan LKPD yang digunakan di sekolah dimana LKPD ini tidak sesuai dengan standar kompetensi dan tujuan pembelajaran yang akan dicapai. LKPD yang digunakan di sekolah terbatas pada file pdf. dan hanya berisikan materi dan latihan soal yang belum dikembangkan sesuai kebutuhan proses pembelajaran yang disebarkan melalui WhatsApp grup masing-masing kelas, mengingat saat ini pembelajaran di sekolah masih online akibat dampak terjadinya pandemi Covid-19.

b) Analisis Peserta didik

Analisis peserta didik dilakukan untuk menelaah karakteristik peserta didik SMA N 1 Batusangkar khususnya kelas X. Analisis dilakukan dengan dua cara, yaitu pertama melakukan diskusi bersama guru sosiologi di sekolah. Diskusi dengan guru sosiologi yang bernama ibu Maidarlis, S.Pd. dilakukan pada hari Selasa tanggal 6 April 2021. Kedua dengan cara melakukan observasi. Dari analisis karakter peserta didik yang peneliti lakukan didapatkan gambaran sebagai berikut:

1. Peserta didik kelas X di SMA N 1 Batusangkar berjumlah 356 orang

2. Khusus di kelas penelitian yaitu kelas X IPS 1 terdapat 40 orang peserta didik, terdiri dari 26 orang perempuan dan 14 orang laki-laki.

3. Peserta didik bersifat terbuka pada perkembangan Ilmu Pengetahuan dan Teknologi (IPTEK) khususnya dibidang IT.

4. Peserta didik kelas X IPS ini salah satu kelas dengan peserta didik yang update terhadap informasi dan IT.

5. Serta motivasi belajar yang cukup tinggi dibandingkan kelas lanny

c) Analisis Materi

Dalam pelaksanaan pembelajaran SMA N 1 Batusangkar digunakan kurikulum 2013 yang mengacu pada standar isi dalam Permendikbud No.21 Tahun 2016. Memuat tentang tingkat kompetensi dan kompetensi inti sesuai dengan jenjang dan jenis pendidikan tertentu. Kompetensi inti meliputi sikap spiritual, sikap sosial, pengetahuan dan keterampilan. Ruang lingkup materi yang spesifik untuk semua mata pelajaran dirumuskan berdasarkan tingkat kompetensi dan kompetensi inti untuk mencapai kompetensi lulusan minimal pada jenjang dan jenis pendidikan tertentu.

Mata pelajaran sosiologi merupakan salah satu mata pelajaran yang menggunakan kurikulum acuan standar isi. Berikut ini adalah tabel penjabaran standar KI dan KD pelajaran sosiologi kelas X berdasarkan standar isi. 
Tabel 4. Kompetensi Dasar dan Indikator Materi

\begin{tabular}{|c|c|c|}
\hline \multicolumn{2}{|r|}{ Kompetensi Dasar (KD) } & Indikator Pencapaian Kompetensi (IPK) \\
\hline 3.3 & $\begin{array}{l}\text { Menganalisis berbagai gejala sosial } \\
\text { dengan menggunakan konsep-konsep dasar } \\
\text { Sosiologi untuk memahami hubungan } \\
\text { sosial di masyarakat }\end{array}$ & $\begin{array}{l}\text { 3.3.1 Menjelaskan pengertian nilai dan norma } \\
\text { 3.3.2 Menganalisis fungsi nilai dan norma }\end{array}$ \\
\hline 3.4 & $\begin{array}{l}\text { Melakukan kajian, diskusi dan mengaitkan } \\
\text { konsep-konsep dasar Sosiologi untuk } \\
\text { mengenali berbagai gejala sosial dalam } \\
\text { memahami hubungan sosial di masyarakat }\end{array}$ & $\begin{array}{l}\text { 3.3.3 Mengkiasifikasikan norma sosial } \\
\text { berdasarkan daya ikatnya }\end{array}$ \\
\hline
\end{tabular}
Sumber: Silabus Sosiologi Kurikulum 2013

Analisis materi yang peneliti kembangkan berdasarkan silabus dilakukan berdasarkan standar isi di atas pada materi nilai dan norma adalah sebagai berikut:

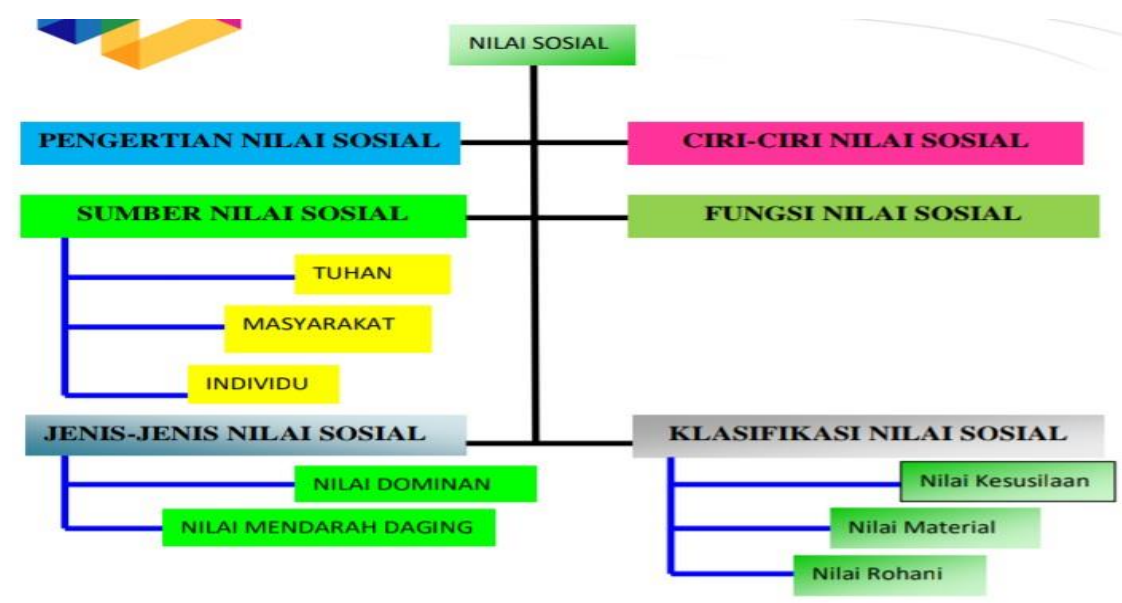

Gambar 1. Peta Konsep Materi Nilai Sosial

(Sumber Bahan Ajar Sosiologi Peneliti, 2021)

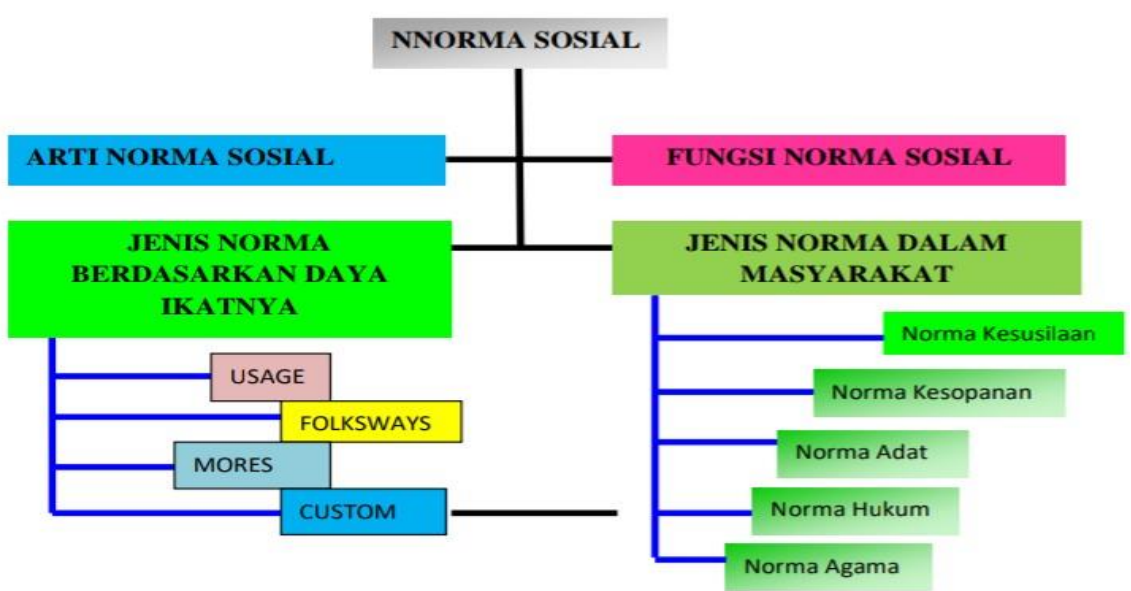

Gambar 2. Peta Konsep Materi Nilai Sosial

(Sumber Bahan Ajar Sosiologi Peneliti, 2021)

Tahap Design (Perancangan)

Jurnal Sikola: Jurnal Kajian Pendidikan dan Pembelajaran Vol. 2, No. 4, Th. 2021 
Pada tahap ini peneliti melakukan rancangan produk yang terdiri atas analisis tujuan pembelajaran, penyusunan materi dan perancangan media.

1) Analisis Tujuan Pembelajaran

Untuk mencapai tujuan pembelajaran tersebut perlu adanya sumber belajar berupa Lembar Kerja Peserta Didik (LKPD). Lembar kerja Peserta Didik ini dikembangkan berbasis weblog. Lembar Kerja Peserta Didik ini dapat digunakan dalam pembelajaran sosiologi disekolah dan dapat diakses oleh pendidik maupun peserta didik.

2) Penyusunan Materi

a) Menentukan dan memahami Kompetensi Inti (KI) dan Kompetensi Dasar (KD) nilai dan norma.

b) Merumuskan indikator yang mendukung Kompetensi Dasar (KD),

c) Mencari sumber bacaan dan soal untuk panduan dalam membuat LKPD,

d) Mencari gambar yang terkait dengan materi nilai dan norma,

e) Membuat lembar diskusi untuk dikerjakan secara berkelompok,

f) Membuat latihan soal untuk dikerjakan peserta didik sebagai uji coba pemahaman terhadap meteri nilai dan norma.

g) Membuat lembar diskusi untuk dikerjakan secara kelompok.

\section{3) Perancangan LKPD}

Setelah penyusunan konsep materi pembelajaran nilai dan norma, maka selanjutnya dilakukan perancangan LKPD berbasis weblog. Pada perancangan ini dimulai dengan membuat blog menggunakan wordpress.com, mendesain tampilan blog seperti tema, tulisan, warna dan tata letak laman didalam blog tersebut.

1. Untuk memulai membuat weblog maka terlebih dahulu $\log$ in ke dalam wordpress.com dengan cara berikut:

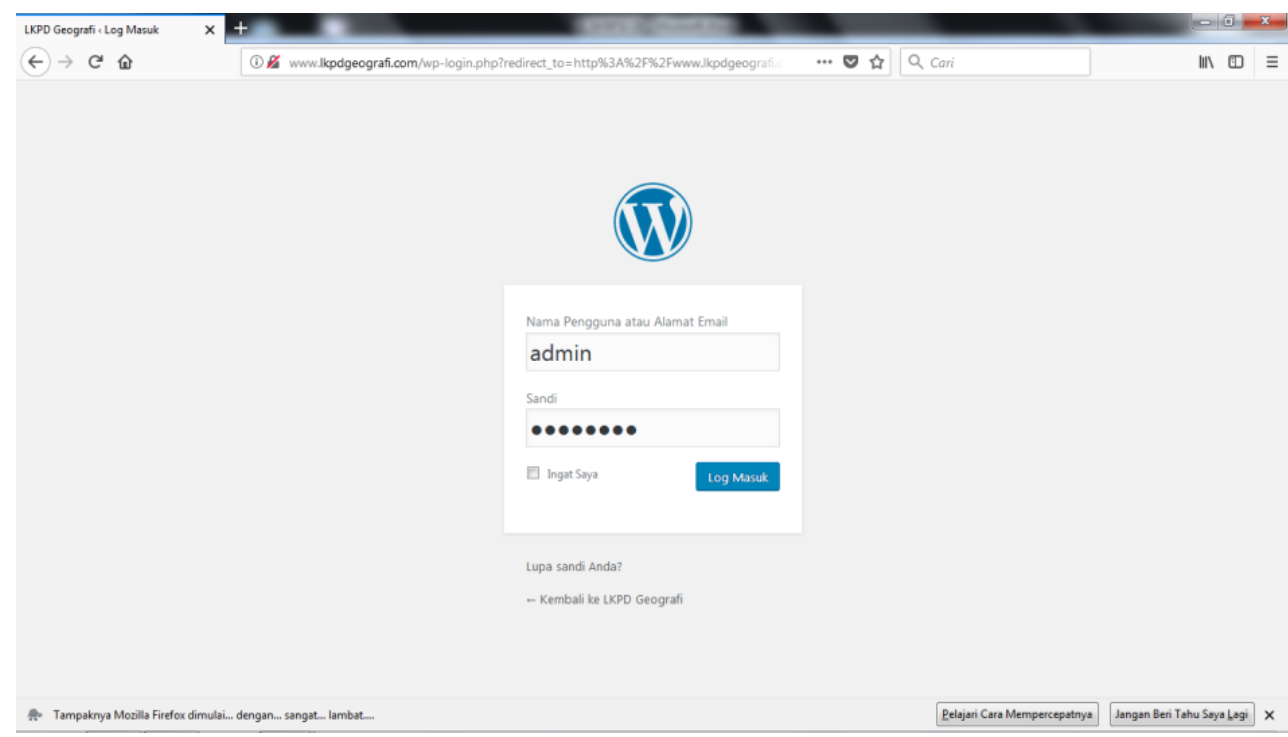

Gambar 3. Tampilan Login ke Akun Wordpress

Sumber: 1kpdsosiologisma.wordpress.com (Dokumentasi pribadi)

Setelah muncul tampilan seperti gambar diatas maka kita masukan username dan password untuk bisa masuk ke dalam weblog yang akan dirancang.

2. Setelah masuk ke dalam weblog maka kita akan melihat tampilan awal seperti berikut ini: 


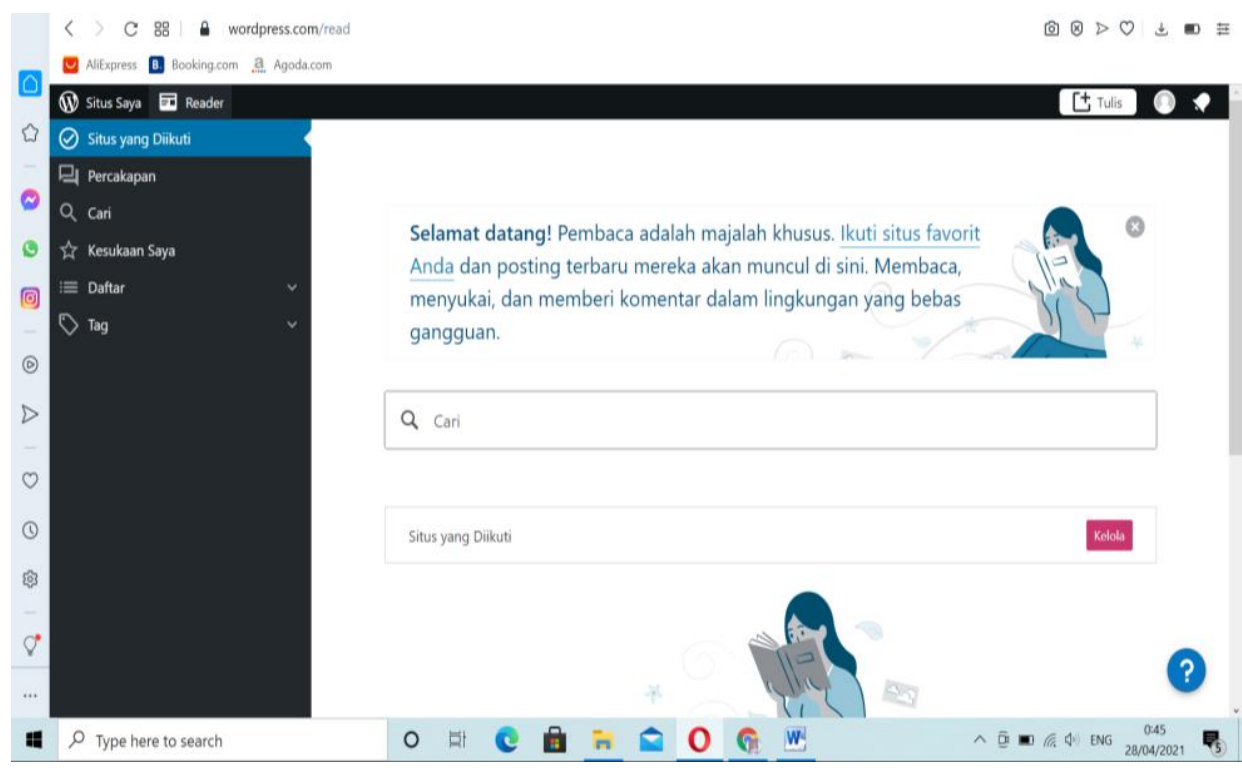

Gambar 2. Tampilan Awal Weblog

Sumber: 1kpdsosiologisma.wordpress.com (Dokumentasi pribadi)

Pada tampilan ini dapat dilihat pilihan menu di sebelah kiri yang berguna untuk mengedit web yang akan kita design, seperti postingan, media, laman, tampilan, wedged dan lainnya.

3. Langkah selanjutnya ialah memilih tema yang sesuai untuk digunakan dalam web. Klik salah satu tema yang tersedia di menu lalu klik OK, seperti gambar di bawah:

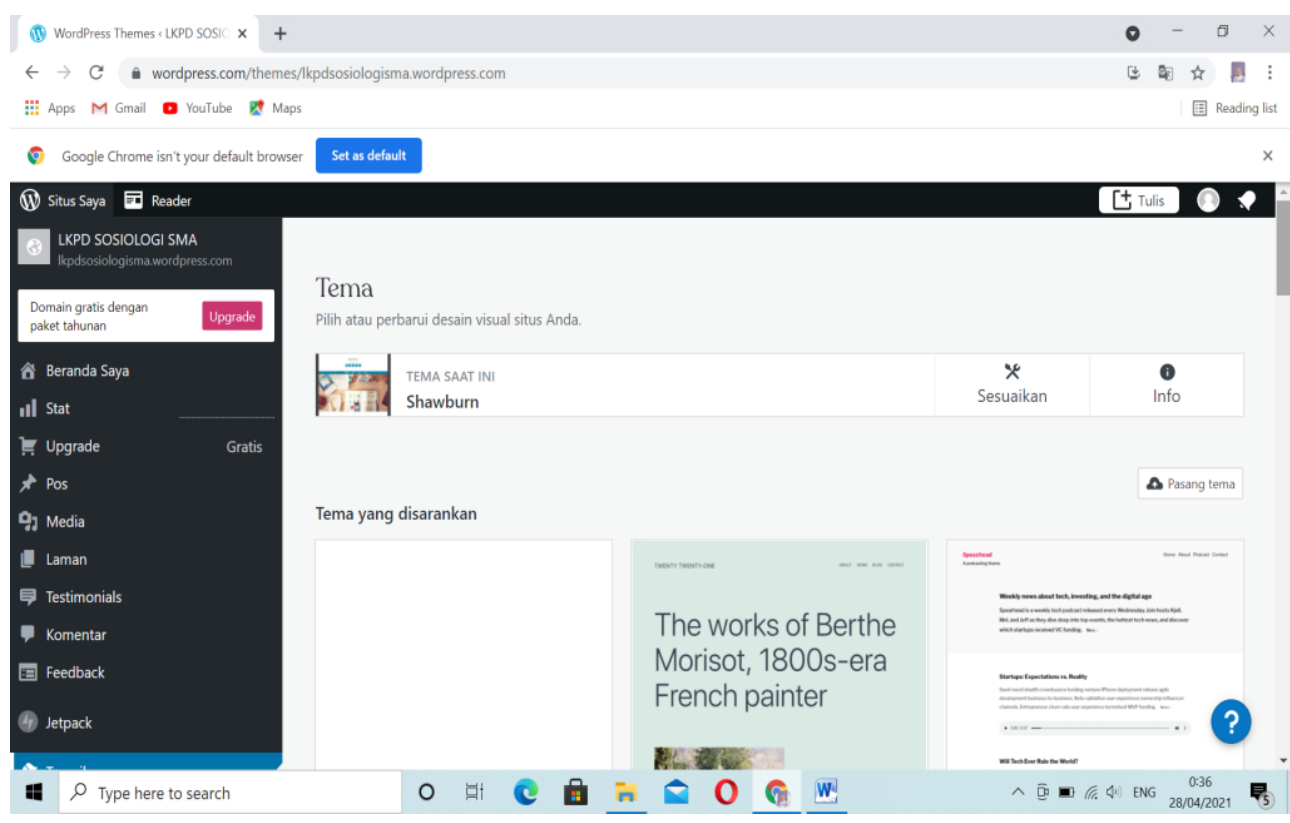

Gambar 3. Tampilan Pemilahan Tema Weblog

Sumber: 1kpdsosiologisma.wordpress.com (Dokumentasi pribadi)

4. Setelah tema selesai ditentukan maka dapat mengatur tampilan menu pada web dengan cara membuat menu seperti beranda, tentang, RPP, materi, LKPD dan lainnya seperti tampilan berikut : 


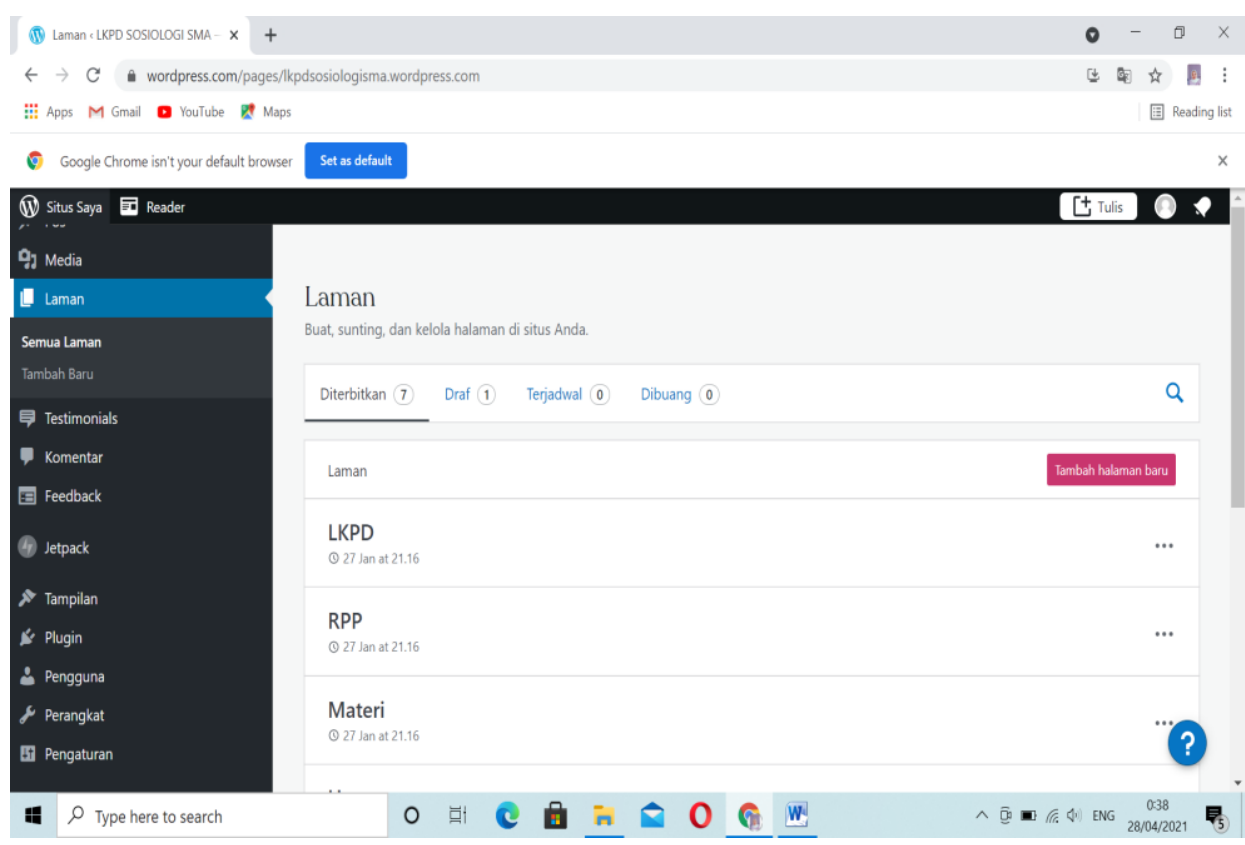

\section{Gambar 4 : Tampilan Pembuatan Menu Bar}

Sumber: 1kpdsosiologisma.wordpress.com (Dokumentasi pribadi)

5. Langkah berikutnya adalah memulai membuat postingan pada web dengan cara klik post lalu tuliskan postingan yang akan dibuat kemudian klik tambah baru di sudut kiri atas, berikut tampilannya:

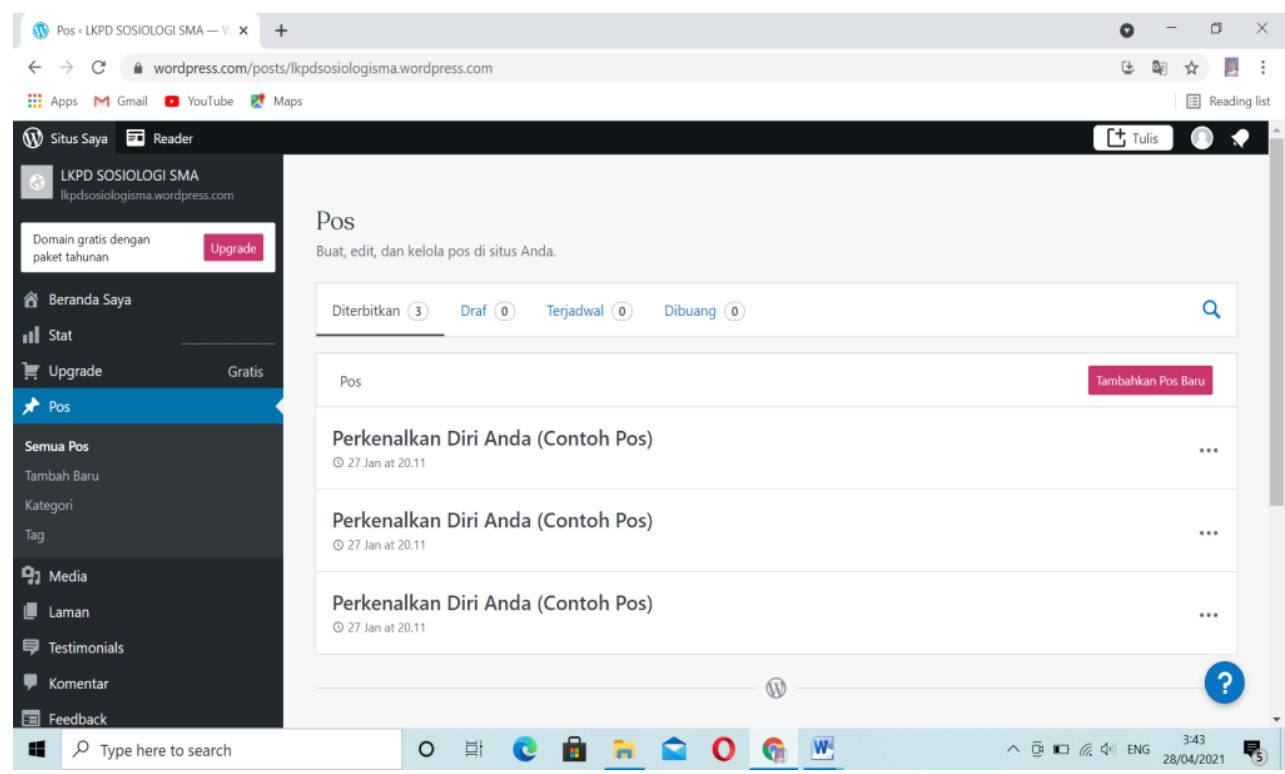

Gambar 5 : Tampilan Pembuatan Halaman Postingan

Sumber: 1kpdsosiologisma.wordpress.com (Dokumentasi pribadi)

6. Setelah semua langkah selesai maka akan muncul web dengan tampilan berikut sebagai postingan pertama yang telah kita buat, misalnya tampilan laman beranda: 


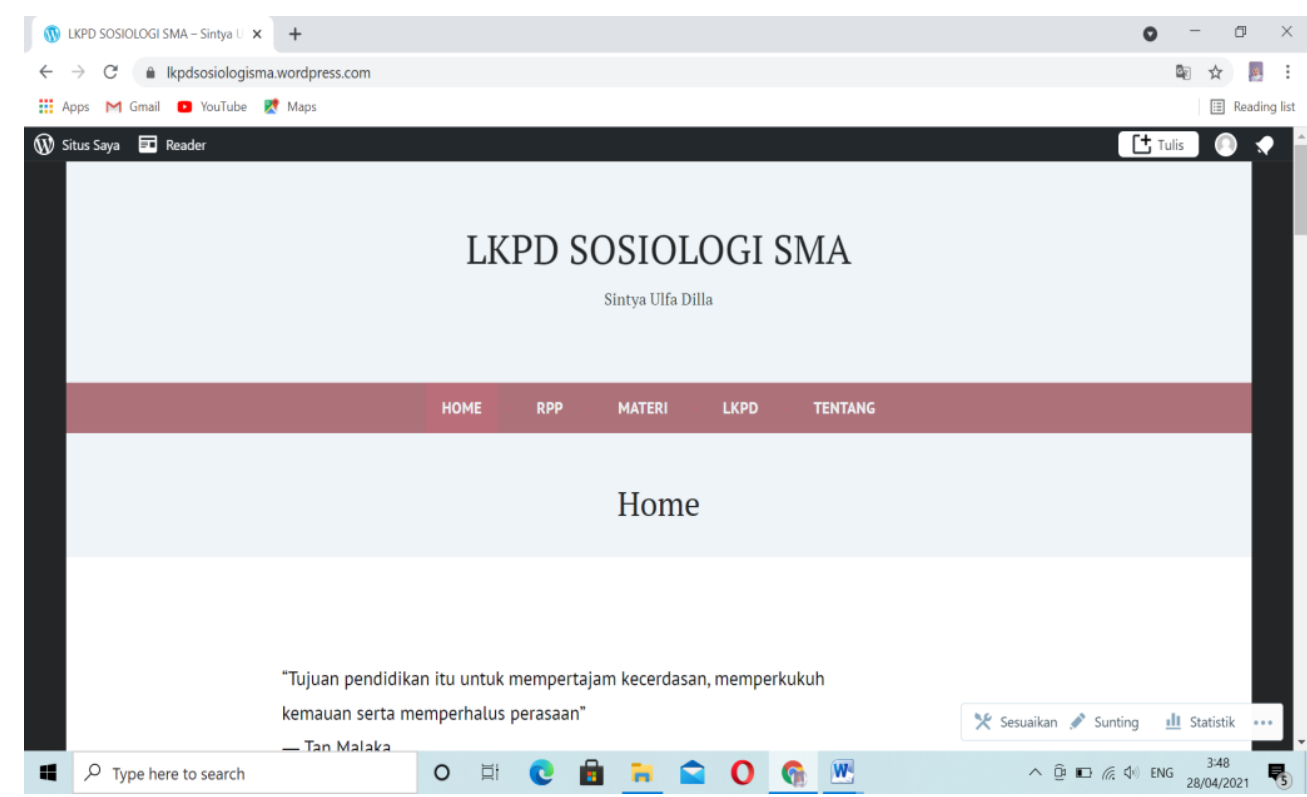

Gambar 6. Tampilan Beranda Web

Sumber: 1kpdsosiologisma.wordpress.com (Dokumentasi pribadi)

\section{Tahap Develop (Pengembangan)}

Pada tahap develop hasil yang diperoleh dari penelitian ini terdiri atas 6 komponen. Keenam komponen ini meliputi: hasil validasi LKPD berbasis weblog oleh ahli materi, hasil revisi LKPD berbasis weblog dari ahli materi, hasil validasi LKPD berbasis weblog oleh ahli media, hasil revisi LKPD berbasis weblog dari ahli media, hasil uji kepraktisan LKPD berbasis web oleh guru dan hasil uji kepraktisan LKPD berbasis weblog oleh peserta didik. Hasil revisi LKPD berbasis weblog dilakukan dengan mempertimbangkan berbagai saran dan masukan dari ahli materi, ahli media dan kepraktisan dari guru dan peserta didik terhadap keterbatasan, kekurangan serta kesalahan yang terdapat dalam LKPD berbasis weblog. Namun pada artikel ini penulis lebih memfokuskan pada produk pengembangan LKPD berbasis weblog dan uji praktikalitas pada pengguna.

1) Hasil Uji Praktikalitas oleh Guru

Penilaian praktikalitas LKPD weblog yang telah dirancang diuji praktikalitas penggunaannya oleh guru pada lima indikator, yaitu: minat dan tampilan, proses penggunaan, pemahaman konsep dan materi, waktu dan evaluasi. Penilaian kelima indikator diatas disajikan pada tabel berikut:

\section{Tabel 5. Penilaian Praktikalis Oleh Guru}

\begin{tabular}{|c|c|c|c|}
\hline No & Aspek & Nilai & Kriteria \\
\hline 1 & Aspek minat dan tampilan & 3,9 & Sangat praktis \\
\hline 2 & Aspek proses penggunaan & 3,7 & Sangat praktis \\
\hline 3 & Aspek pemahaman konsep dan materi & 3,6 & Sangat praktis \\
\hline 4 & Aspek waktu & 4 & Sangat praktis \\
\hline \multirow[t]{3}{*}{5} & Aspek evaluasi & 4 & Sangat praktis \\
\hline & Jumlah & 19,2 & \\
\hline & Rata-rata & 3,84 & Sangat praktis \\
\hline
\end{tabular}

Sumber: Data Primer, 2021 
Berdasarkan tabel di atas maka diperoleh hasil penilaian kepraktisan dari kelima aspek berkisar antara 3,6 sampai 4. Nilai rata-rata kepraktisan oleh guru adalah 3,84. Jadi penilaian kepraktisan oleh guru berada pada kategori sangat praktis.

2) Hasil Uji Praktikalitas oleh Peserta didik

Penilaian praktikalitas penggunaan LKPD berbasis weblog oleh peserta didik terdiri dari lima aspek yaitu: minat dan tampilan, proses penggunaan, pemahaman konsep dan materi, waktu dan aspek evaluasi. Penilaian kelima indikator di atas disajikan pada tabel berikut:

Tabel 3. Penilaian Praktikalis Oleh Peserta didik

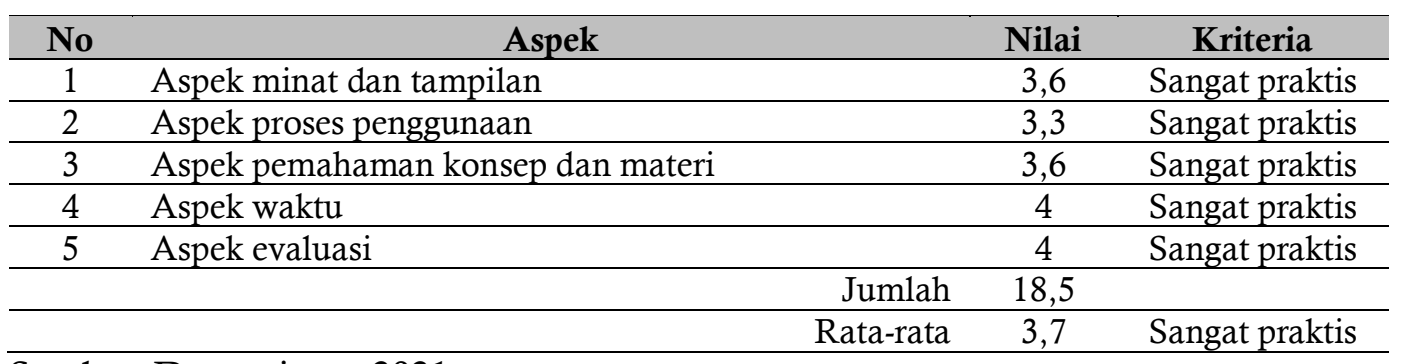

Sumber: Data primer, 2021

Berdasarkan tabel di atas maka diperoleh hasil penilaian kepraktisan dari kelima aspek berkisar antara 3,3 sampai 4. NiIai rata-rata kepraktisan oleh peserta didik adalah 3,7 (kategori sangat praktis).

\section{Pembahasan}

Hasil penilaian kepraktisan LKPD sosiologi berbasis weblog diperoleh dari penilaian instrumen kepraktisan oleh guru dan peserta didik. Hasil kepraktisan oleh praktisi menunjukan bahwa LKPD sosiologi berbasis weblog sangat praktis digunakan dalam pembelajaran di sekolah. LKPD sosiologi berbasis weblog ini dapat dikatakan praktis oleh pengguna karena weblog tersebut sudah memenuhi beberapa kriteria diantaranya : kemudahan dalam penggunaan, kejelasan dalam penggunaan, pengerjaan evaluasi, kemudahan komunikasi, memotivasi dan berpengaruh terhadap penguasaan materi yang disajikan. (Siska, 2016). LKPD ini dinilai oleh pengguna dengan hasil mudah untuk digunakan dan dipahami oleh peserta didik. Mudjijo dalam (Hervina, 2018) mengemukakan bahwa kepraktisan menunjukkan pada tingkat kemudahan penggunaan, pelaksanaan dan penafsiran hasilnya. Weblog merupakan media yang tepat sebagai sumber belajar karena mudah digunakan dan menggabungkan berbagai fitur seperti video, foto, grafik, peta, musik, dan perangkat audio (Chen, 2013).

Hasil uji kepraktisan diperoleh dari instrumen lembar uji kepraktisan menurut peserta didik dan guru terhadap LKPD berbasis weblog. Berdasarkan nilai yang diperoleh dari uji kepraktisan dapat disimpulkan bahwa LKPD belajarberbasis weblog sangat praktis digunakan dalam proses pembelajaran Sosiologi. Pertama, karena LKPD berbasis weblog ini praktis karena tampilannya menarik dan dapat menambah minat peserta didik.(Elfina \& Sylvia, 2020).

Kedua, penggunaan LKPD berbasis weblog ini mudah digunakan oleh peserta didik. Hasil ini dapat dipengaruhi karena LKPD berbasis weblog ini dirancang melalui penelitian R \& D yang terukur secara sistematis langkah analisis dan pengembangannya, dikembangkan sesuai dengan langkah-langkah penulisan LKPD, memiliki struktur jelas dan konten yang sesuai, dan memiliki alat evaluasi yang dapat diakses oleh peserta didik secara online.

\section{Kesimpulan}

Dapat disimpulkan bahwa penggunaan Lembar Kerja Peserta Didik (LKPD) berbasis weblog ini praktis untuk digunakan. Hasil kepraktisan LKPD sosiologi berbasis weblog dari dua 
orang guru sosiologi diperoleh nilai 3,5 dengan kategori sangat praktis. Untuk hasil praktikalis dari peserta didik diperoleh nilai 3,5 dengan kategori sangat praktis.

\section{Daftar Pustaka}

Aprilia, N. R. (2019). Pengaruh Pemanfaatan Sumber Belajar terhadap Motivasi Belajar Sejarah di SMA se-kota Pekalongan. Universitas Negeri Semarang.

Bambang, W. (2008). Teknologi Pembelajaran Landasan dan Aplikasinya. Jakarta: Rineka Cipta.

Chen, T.-C. H. and C.-C. (2013). Animating Civic Education: Developing a Knowledge Navigation System using Blogging and Topic Map Technology. Educational Technology \& Society, 16(1), 79-42.

Daryanto. (2014). Siap Menyongsong Kurikulum 2013. Yogyakarta: Gava Madia.

Elfina, S., \& Sylvia, I. (2020). Pengembangan Lembar Kerja Peserta Didik (LKPD) Berbasis Problem Based Learning (PBL) dalam Meningkatkan Kemampuan Berpikir Kritis Siswa Pada Mata Pelajaran Sosiologi di SMA Negeri 1 Payakumbuh. Jurnal Sikola: Jurnal Kajian Pendidikan dan Pembelajaran, 2(1), 27-34. https://doi.org/10.24036/sikola.v2i1.56

Hervina. (2018). Pengembangan Sumber Belajar Berbasis Weblog Pada Materi Mata Pelajaran Geografi Kelas X di Sma. Buana, 2(1), 192-204.

Madcom. (2010). Menggenggam Dunia dengan Internet. Yogyakarta: Penerbit Andi.

Manurung, E. H. (2018). Pengembangan Lembar Kerja Peserta Didik (LKPD) Berbasis Weblog Pada Materi Pteridophyta Untuk Peserta Didik Kelas X SMA. Universitas Jambi.

Munir. (2008). Kurikulum Berbasis Teknologi Informasi dan Komunikasi. Bandung: Alfabeta.

Nurcahyo, P. A. (2016). Pengaruh Penggunaan Media Pembelajaran Terhadap Hasil Belajar Siswa Mata Pelajaran Kelistrikan Mesin \& Konversi Energi di SMK N 2 Depok. Universitas Negeri Yogyakarta.

Politeknik, T. (2012). Pelatihan Penulisan Blog Wordpress. https://pdfslide.net/documents/ pelatihan-penulisan-blog-wordpress-menggunakan-cms-untuk-membangun-blog caranya.html

Pratama, R. A., \& Siregar, A. (2019). Pengembangan Lembar Kerja Peserta Didik (LKPD) Berbasis Scaffolding Untuk Melatih Pemahaman Konsep. Indonesian Journal of Science and Mathematics Education, 2(1), 84-97.

Refika, R., Suasti, Y., \& Nofrion, N. (2018). Weblog Pada Materi Pembelajaran Geografi Kelas X. Buana, 2(3), 738-747.

Sari, K. N. (2018). Pengembangan Lembar Kerja Siswa (LKS) Berbasis Moodle Sebagai Media Pembelajaran Interaktif Pada Materi Archaebacteria dan Eubacteria. Universitas Islam Negeri (UIN) Raden Intan Lampung.

Setyosari, S. (2010). Metodologi Penelitian Pendidikan. Jakarta: Rajawali Pres.

Siska, H. (2016). Pengembangan Lembar kerja Elektronik Berbasis Web Mata Kuliah Analisis Verktor. Universitas Jember.

Sudjana, N. (2006). Penilaian Hasil Proses Belajar Mengajar. Bandung: Remaja Rosdakarya.

Syamsurizal, Epinur, \& Marzelina, D. (2014). Pengembangan Lembar Kerja Peserta Didik (LKPD) Non Eksperimen Untuk Materi Kesetimbangan Kimia Kelas XI IPA SMA N 8 Muaro Jambi. Jurnal Of The Indonesia Society Of Integrated Chemistry, 6(2), 35-42.

Sylvia, I., Anwar, S., \& Khairani, K. (2019). Pengembangan Instrumen Penilaian Autentik Berbasis Pendekatan Authentic Inquiry Learning Pada Mata Pelajaran Sosiologi di Sekolah Menengah Atas. Socius, 6(2), 103-120. https://doi.org/10.24036/scs.v6i2.162

Trianto, T. (2010). Mendisain Model Pembelajaran Inovatif Progresif: Konsep, Landasan dan Implementasinya Pada Kurikulum Tingkat Satuan Pendidikan. Jakarta: Kencana. 
Usra, R. H. (2018). Pengembangan lembar Kerja Peserta Didik (LKPD) Berbasis Web Pada Pembelajaran Geografi di SMA N 1 Batusangkar. Jurnal Buana, (1), 238-249. 